\title{
Alejandro de la Sota's modern villages: vernacular abstraction and surrealist modernity
}

\author{
Jean-François Lejeune ${ }^{, 1,1}$ \\ ${ }^{1}$ University of Miami School of Architecture, 33146 Coral Gables, United States
}

\begin{abstract}
Asked to implement General Franco's ambitious "hydro-social dream" of modernization of the countryside, Falangist planners, engineers, and architects of the Instituto Nacional de Colonización (I.N.C.) developed a national strategy of "interior colonization" that, along with the reclamation of extensive regions, included the construction of 302 modern pueblos between 1944 and 1970. Alejandro de la Sota (1913-1996) was one of the first five architects of the I.N.C. He designed Gimenells (1943), which set up the standards for the 1940s, and then four innovative villages: Esquivel (1952), Entrerríos (1954), Valuengo and La Bazana (1956). Based on research within the archives of the Fundación Alejandro de la Sota and the Ministry of Agriculture, this paper summarizes the modernity of his pueblos: the separation of traffic, the propagandistic concept of the open plaza, the volumetric abstraction of the vernacular house, and his ironic use (as understood by Ortega y Gasset) of the Spanish classical. The research emphasizes how de la Sota transcended the functionalist elements of modernity in order to mobilize memories of the real and produce a "surreal" reality. In so doing, he reversed the fundamental reference to the countryside that characterized Spanish surrealism to bring surrealism within the process of Franquist rural modernization.
\end{abstract}

\section{Introduction}

The 1898 defeat of Spain in the Spanish-American War and the subsequent loss of the last colonies opened a major intellectual, moral, political and social crisis. The aftershock provided an impetus for many writers and intellectuals to diagnose their country's ills and to seek ways to jolt the nation out of its predicament. As they were forced to focus inwards, the rediscovery of the Spanish heartland, away from the big cities, was a physical, geographical, cultural, and also architectural process that would spur a radical revision of national identity. Politician, jurist, economist and historian Joaquín Costa Martínez (1846-1911) became the most important representative of Regenerationism, a multi-disciplinary movement whose objective was the modernization of the country with a focus on the impoverished countryside [1]. For Costa and his friends, modernization meant the remaking of Spanish nature and thus of the rural world. The erratic fluvial system, the uneven rainfalls, and the long periods

\footnotetext{
${ }^{1}$ Corresponding author: flejeune@miami.edu
} 
of drought had hampered agricultural productivity for centuries, and the complex answer involved the need for major hydrographical engineering of the country: "the truth is that Spanish agriculture finds itself strongly subjected to this inexorable dilemma: to have water or to die...." [2]

Modernity became, in the words of geographer Erik Swyngedouw, "a geographical and environmental project or, more accurately, about the production of new geographies and new 'natures,' both materially and symbolically" [1]. By the 1930s, decades of debates and legal initiatives, intensified during Primo de Rivera's dictatorship and the Second Republic, had established a socio-political consensus that an ambitious state-driven hydraulic policy was the sine qua non condition of the modernization of Spain. Even before the end of the War, General Franco had put into motion the grand "hydro-social dream" of modernization of the countryside [1]. The Instituto Nacional de Colonización (I.N.C.) was created in October 1939 to implement his rural utopia. Over three decades, the architects and planners of the institute worked in collaboration with State's hydraulic engineers to create new man-made landscapes of dams, irrigation canals, electric power plants, and new villages. Each pueblo de colonización (from 100 to 200 houses in average) was assigned to one architect and designed as a small urban center, focused on a plaza mayor which embodied the political ideal of civil life under the national-catholic regime and whose form evolved from a Sitte-influenced traditional design in 1940s to a more organic Aalto-inspired vision after $1953[3,4,5]$.

Surprisingly, Swyngedouw's critical analysis of the created techno-nature as a result of water control dismissed the whole experience of interior colonization. Whether this political process was an economic and social success has remained in question, yet it is indubitable that the foundation of 302 new villages and the settlement of about 65,000 colonists and family members represented a major component, physical and human, of the new landscapes. Through human colonization, the techno-nature was transformed into Kulturlandschaften (cultural landscapes), i.e., "the human achievement of transformation in context with nature whereby the growth of culture parallels the growth of nature, aiming together towards a heightening of the natural world through manmade cultural interventions" [6].

\section{Pueblos \& Abstraction}

Alejandro de la Sota (1913-1996), one of the most important modern architects of the post-Civil War period - his masterpieces are the Gobierno Civil of Terragona (19571964) and the Gymnasium of the Maravillas School (Madrid, 1960-1962) - was one of the first five architects of the I.N.C. [7, 8]. His plans for Gimenells (1943) set up the standards for the next ten years. As he wrote, it was important to achieve a variety of urban form that "without being overly irregular would be sufficient to evade the rigorous aspect of a town of grid-like pattern" [9]. Hence, he designed Gimenells as a slightly distorted grid divided into four sections by two main streets - the main one as Calle Mayor - intersecting at the plaza mayor, with the church tower terminating one or more of the entrance vistas. The town hall also faced the square and was identified by a shorter tower. The square was representative of the State and the Church, as well as a place to congregate for shopping activities and fiestas, usually identifiable with the protective arcades on all mixed-use sides.

The monocentric model established in Gimenells became the most common pattern of the entire colonization. José Borobio Ojeda popularized it with multiple variations throughout Aragón and imported it in Extremadura with the larger town of Valdelacalzada 
(1951). Other architects continued to develop it in Andalusia and particularly within the Plan Badajoz established in 1952 for the colonization of the Guadiana river basin. In 1939 the newly created National Institute of Housing had enacted the Ordenanzas de la Vivienda, a set of regulations based upon pre-Civil War research that established all functional and technical requirements for the colonist houses [10]. As a result, the typology within the I.N.C towns was regulated and consisted mainly of a small number of patio-based housing types, with an additional type of apartment located above the arcades of the plaza for employees and retail owners.

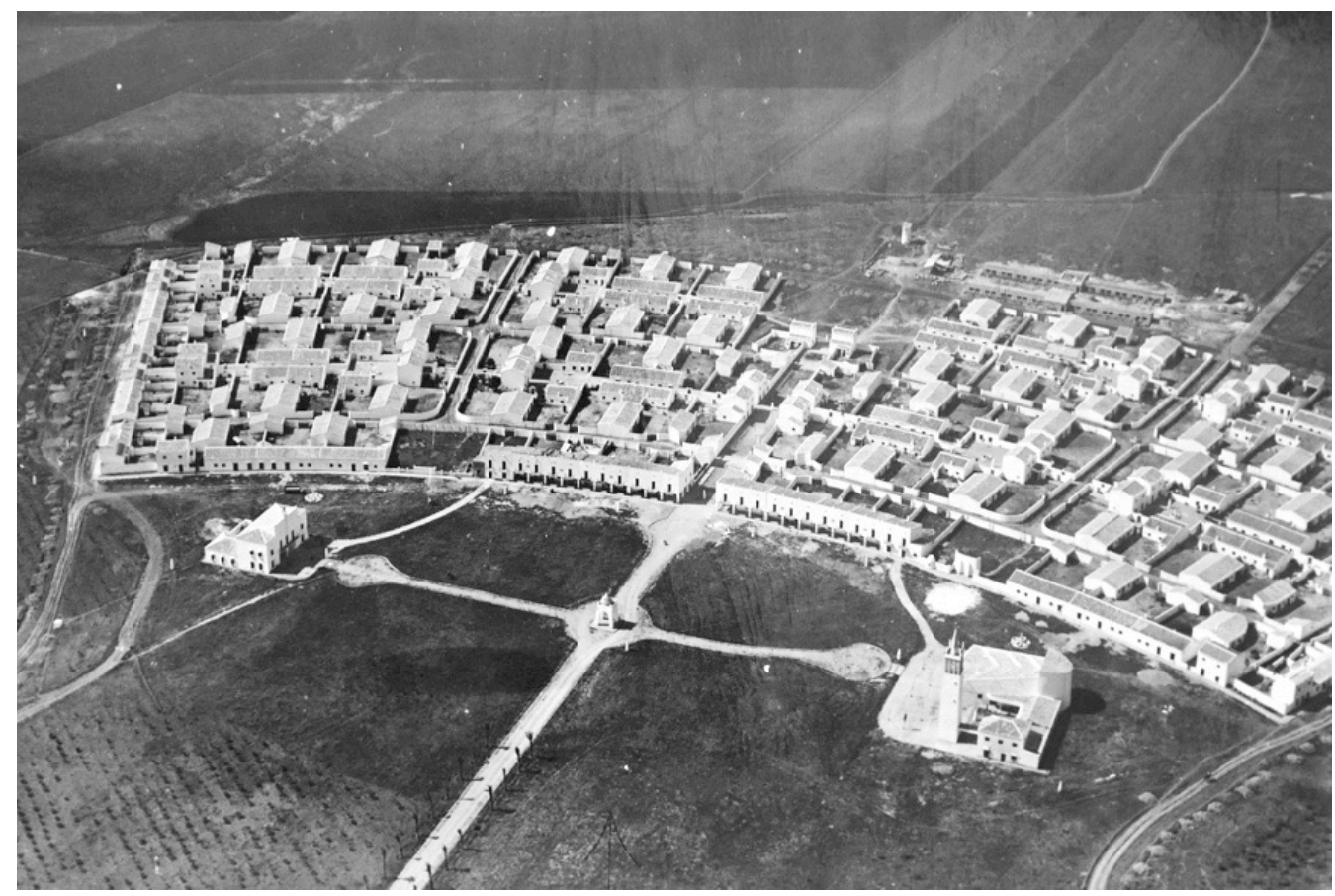

Fig. 1. Aerial view of Esquivel. (Source: @ MAGRAMA).

De La Sota was the architect who broke all formal rules with the village of Esquivel, a short distance from Seville. Designed from 1952 it responded to the wave of change that was shaking the Spanish architectural environment. The Fifth National Assembly of Architects of 1949 opened the Spanish architectural world to an international forum after ten years of isolation. Guest lecturers Alberto Sartoris and Gio Ponti argued for a new architecture of "mediation" whose modernity would reflect "the rational and functional concept of the art of building... as old as the world and born on the coasts of the Mediterranean," thus reconnecting with the pre-Civil War experiments of vernacular modernism [11, 12]. Josep Antonio Coderch's projects for Sitges in the 1940s, the birth of Grupo $R$ in Barcelona (1951), and the Spanish Pavilion for the IX Milano Triennale (1951), provided the impulse and the cultural alibi, not only to adopt a stripped-down vernacular as a politically acceptable form of Spanish modernity but also to set up a more organic relational system between buildings and their environment. Likewise, whereas the reference to the Escorial had dominated Spanish architecture during the 1940s, many saw in the Alhambra (Manifesto of the Alhambra, 1953) a more appropriate reference to the modern condition of postwar Spain [13]. Accordingly, the search for a more abstract urban form to match the modernized vernacular implied that the grid and the block could lose their absolute character and be substituted by more 
informal plans and relationships between city and nature.

De la Sota designed Esquivel as a symmetrical fan-shaped figure, whose "rigidity" reflected the fact that "it was born all at once on a flat terrain" [14]. The first innovation, based upon a study by Alejandro Herrero, was a network of pedestrian-only streets and small squares that gave access to the front of the patio houses [15]. On both sides of the central pedestrian axis and around the village, another system of streets, wider and bordered by high courtyard walls, concentrated all the agricultural traffic. Yet, the real innovation of Esquivel was a formal and symbolic one: the long, symmetrical and curved façade that faced the regional road across a large park, within which stood the town hall, a garden pavilion, and the church complex with its own patio. For the first time in the I.N.C. program, church and town hall did not contribute urbanistically as the walls of a square, but rather rose as a corporeal and freestanding complex within the landscape. In a somewhat ambiguous way, he concluded, "in the end, the good impression that Esquivel has to give from the main road is completely assured; and that is the point of propaganda [16: 2].

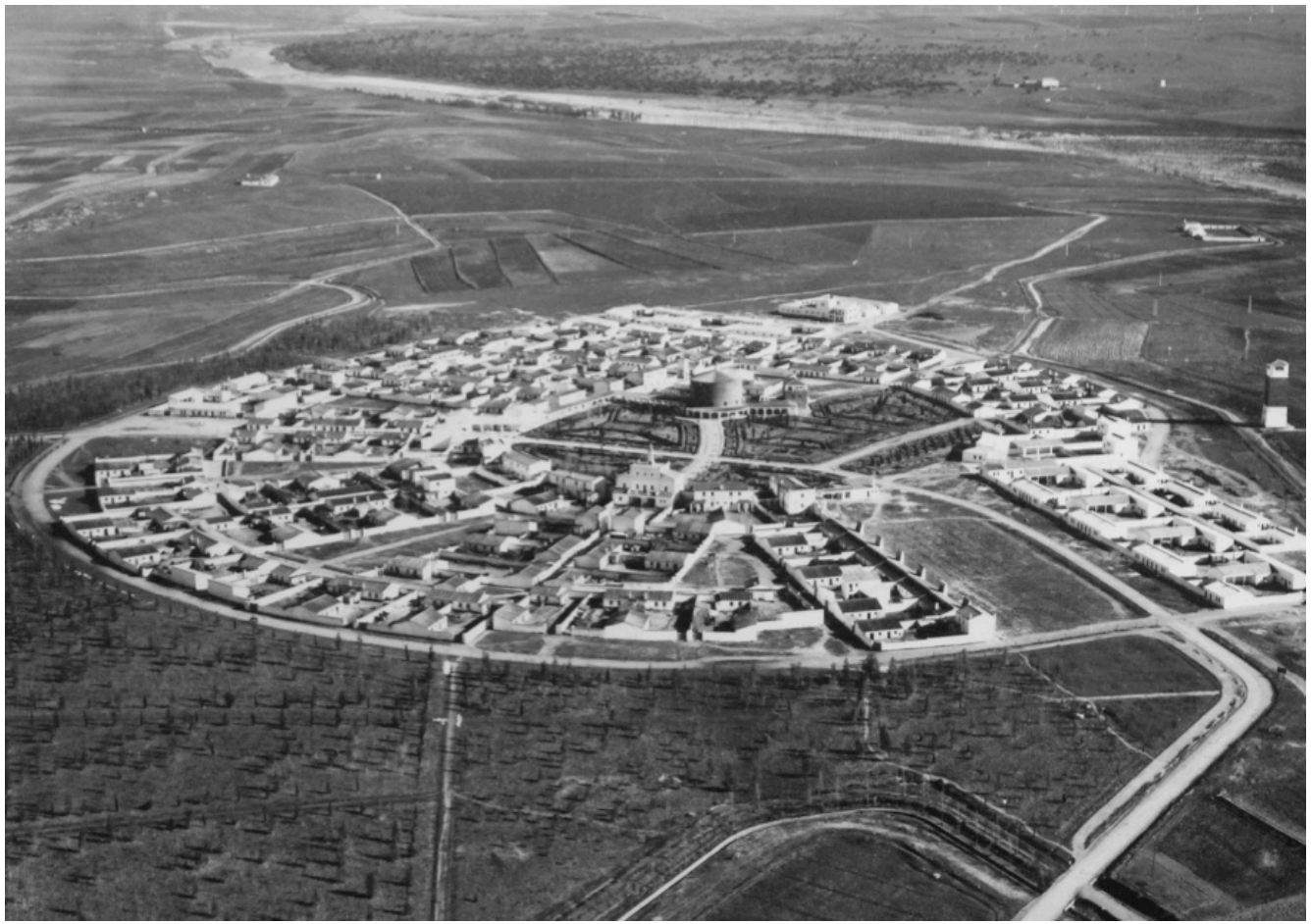

Fig. 2. Aerial view of Entrerríos. (Source: ( MAGRAMA).

An early sketch for de la Sota's third village, Entrerríos (1954), shows the town fully circular as a modern reinterpretation of the Renaissance diagram of the Ideal City. He partially maintained the concept and organized the plan around "a square in elliptical form" within which he designed a circular church and its attached rectory [16: 1]. A series of pedestrian diagonals connected the park to the neighbourhoods while the town hall faced the park with a retail arcade on both sides. In his last pueblos of La Bazana and Valuengo (1956), he achieved what he aimed to realize from the beginning of his work at the I.N.C., i.e., an almost complete absence of recognizable form. Formless because in contrast with his three previous projects, he fulfilled the difficult task of designing a place that appears to have been there, in other words, whose layout does 
not reveal the design intent.

Until Esquivel, most I.N.C. architects deployed a vernacular-based architecture, moderately regionalist for the residential fabric and the plaza mayor, more stylistically traditional for the public architecture such as the town hall and especially the church. For his last four villages, de la Sota did not reinvent the popular architecture of the houses. He made it more abstract, modified the proportions, reduced the size of openings to provide more white walls, flattened the surfaces by eliminating ornaments, but maintained the traditional grillwork. Only in rare cases like the curved façade of Esquivel, was the connection to rationalism made fully manifest as he wrote, "In Esquivel, there is rationalism" [17]. Yet, it is in the interaction between urban form and residential architecture that his real innovations could be found, around the plazoletas and along the central axis. There he used symmetry in a "metaphysical" way, beautifully reflected in the simple sketches that at some moments make public space acquire a quasi-anthropomorphic character.

\section{Surrealism and countryside}

Spain's role in the history and development of the Surrealist movement before the Civil War generated a large amount of studies and exhibitions. Salvador Dalí, Luis Buñuel, Óscar Domínguez, Joan Miró, and Pablo Picasso were some of the most representative artists of a movement which developed a specific Spanish identity, with definite themes, places, and techniques of representation. For most Spanish Surrealists, the countryside was one fundamental reference, both thematic and geographic. As examples, in early $20^{\text {th }}$ century, the masía - a type of rural construction connected to a large estate, often fortified - became a symbol of Catalan identity [18]. Like many artists, Miró used it as a major source as seen in La Masia (1921-22) and La tierra labrada (1923-24). In this painting whose gold and ear motives derived directly from Hyeronimus Bosch, the elements of the masía dominate the composition: "the furrows of the field, the fig tree, the agave, the goat, the lizard, the dog, the rabbits, the rooster, the snail, the newspaper... and more elements, such as... the snail, the worm, the birds, the farmer and the ox" [19] . In 1924, Dalí painted an enigmatic portrait of Luis Buñuel, shown as a very solemn man looking into the distance while, in the background, the cubic volumes of a village seem to anticipate the architecture of the pueblos de colonización. Likewise, his Muchacha vista de la espalda of 1925 portrays the girl in front of a country landscape that is, at once, realistic and surrealist by the degree of abstraction of some of its parts. Óscar Domínguez also set up his major paintings in the countryside, such as Toro $y$ torero (1935), and his Souvenir de Paris, an extraordinary framing of Paris seen from the nearby countryside and the underground. Very important for the Madrid artistic circles was the creation in 1927 of the Escuela de Vallecas, a group of surrealist artists led by sculptor Alberto Sánchez Pérez and painter Benjamín Palencia who realized initiatory promenades in the Madrid countryside and painted this rural landscape as a void in transformation, often with the apparition of reduced architectures and other objects.

Surrealism did not vanish with the Civil War, but its second phase under Franquism has received considerably less attention. As Patricia Molins wrote for the exhibition Campo cerrado: "Surrealism was not perhaps the dominant artistic option after the Civil War, but through its variants and infiltrations in the realm of the popular, it provided a strategy that served as a refuge, an escape valve and critical mechanism against a reality with which few could or wanted to identify" [20]. The Falange's approach to 
surrealism reflected the ambiguity and the contradictory views that moulded its overall approach of the new political and socio-cultural situation. The liberal wing supported it as a style that matched its 'revolutionary' aspirations; the conservative side intended to destroy its fame in light of its anti-Christianism and irreverent approach. In 1946, Luis Castellanos, a leader of postwar surrealism, coined the expression of "invented reality" to refer to the attitude of detachment from the immediate reality that characterized preand post-Civil War surrealism [20]. As I will argue, it can be applied to interpret de la Sota's method of reflection and design. Along his life, he often reported that he intensely studied vernacular architecture but recorded it in his mind more than through sketches and photographs. Hence his claim that he created the architecture of Esquivel and his other villages by mobilizing the memory of the real could be indeed interpreted as an urban and architectonic version of "invented reality" [21].

\section{Surrealism in the pueblos}

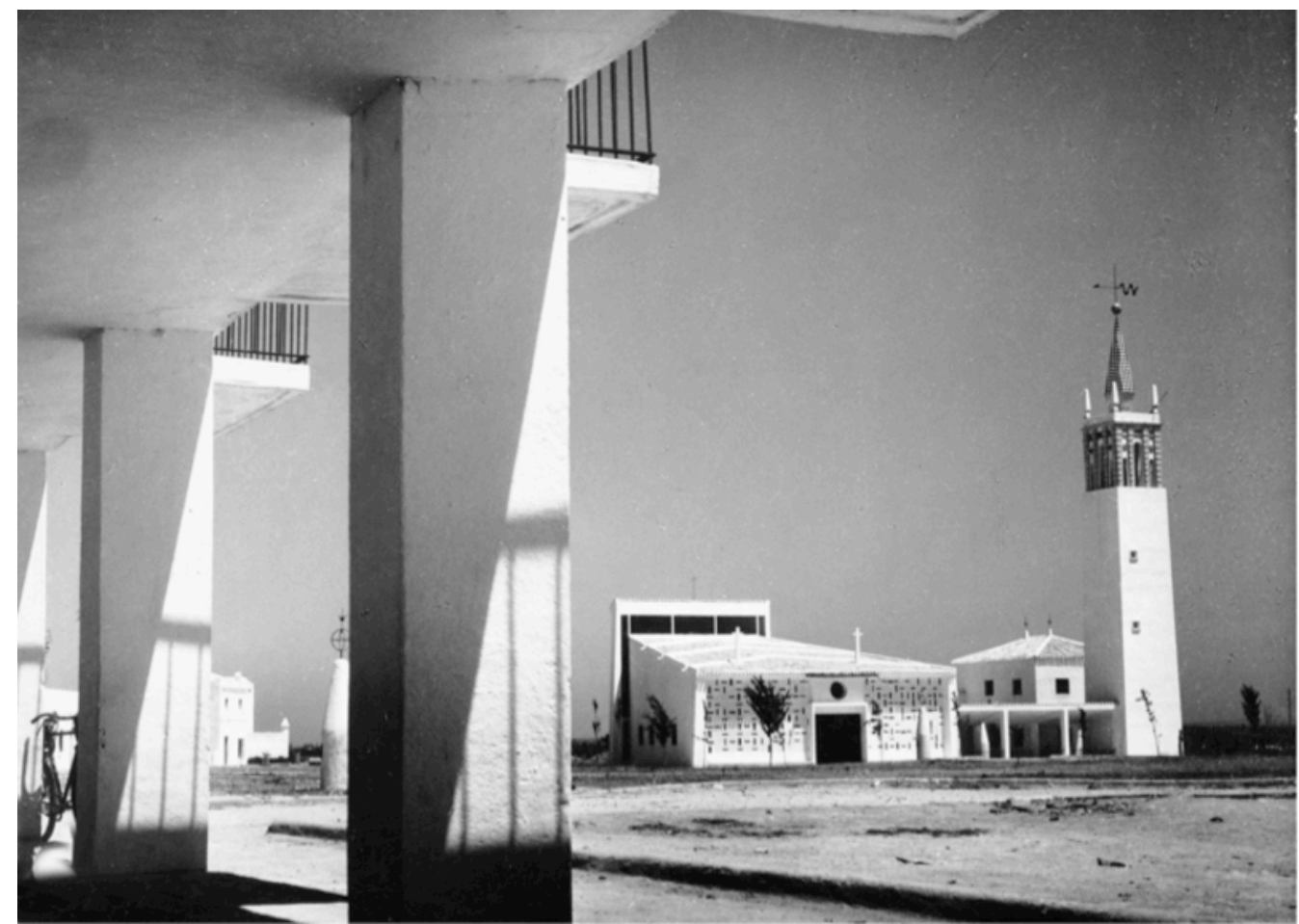

Fig. 3. View of the square of Esquivel. (Photo: Kindel. Source: (c COAM)

Esquivel's urban spaces were traditional, yet, as William Curtis wrote, "they were abstracted in order to adapt them to a new order and a new landscape." And he added: "the forms of the building are those that are close to a regional expression. But, these are not vernacular imitations, there is in them a bit of surrealism" [22]. At the same time, it is significant to read the form of the town, the abanico, not as a functional necessity that emphasizes the artificiality of the process, but as a direct reference to a daily object of Andalusian life, the fan. In doing so, de la Sota deviates the meaning of the object toward a surrealist understanding of it as part of the popular and folkloric. In Entrerríos as well, his sketches of the circular brick church, seen from the arcade and standing alone within the park/plaza, brings to mind De Chirico's 
metaphysical painting, usually understood as a form of surrealism in the Italian context. Likewise, for Guerra Sarabia and Pinto Puerto, his architecture appears "saturated with surrealist references with which it seems to seek signs of identity through an advanced ideology... The splendor, unreal and illusory, of the forms of Sanchez's art, is reflected here and, at the same time, produces an effect of utopia come true" [23]. Beyond the practical and propagandistic explanations, the new plaza of Esquivel, and the suggestive sketch that the architect used to represent it suggest a paradoxical, if not surrealist, image of rural urbanity.

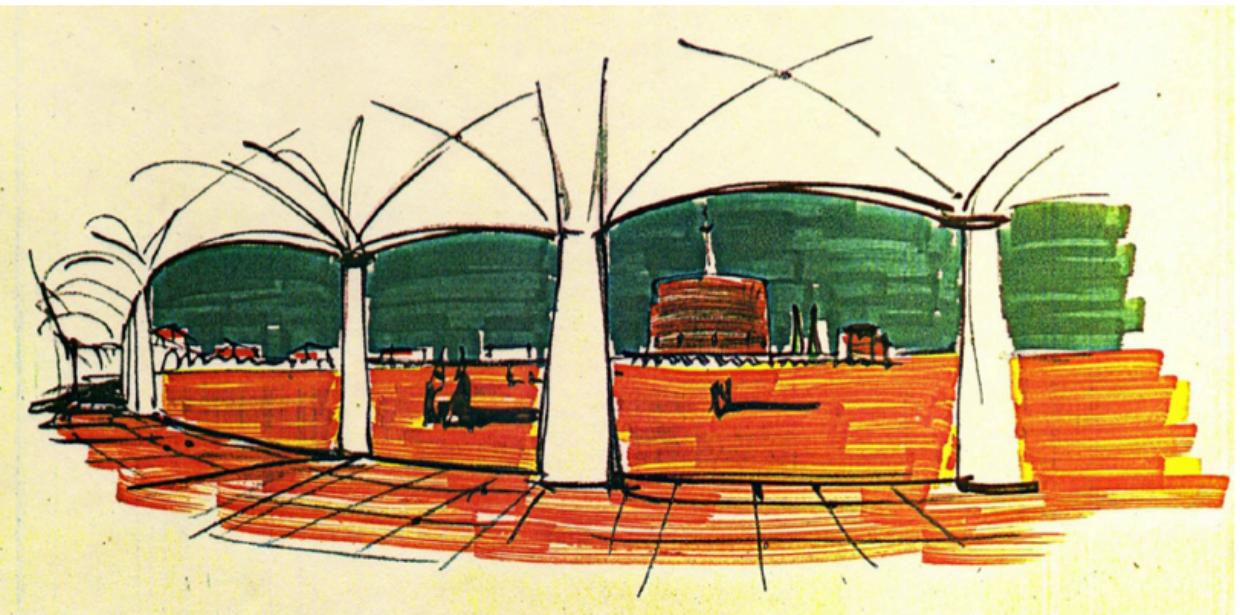

Fig. 4. Sketch of the square in Entrerríos. (Source: (c) Fundación Alejandro de la Sota).

As Alejandro de la Sota wrote, the campanile reflects the work "of the most expert mason and artist involved" [14]. It is the work of an artist, albeit a surrealist one capable of transforming the church tower into an ensemble of objets trouvés without any connection of form or appearance between them, "an assemblage that emulates the models by Ángel Ferrant" [24]. Similarly, the pavilion that he placed on axis with the central street reflects his interest in Antonio Gaudí and Josep Maria Jujol, and all what their works in Catalonia contains of what would become known as surrealism. With its multi-colored ceramics and the delicate ironwork that floats on top of the cupola and holds the name of the town, it appears as a surrealist figure in front of nature. In similar fashion, the town hall reveals de la Sota's critical distance toward the civic structures but also his attempt to produce a genuine architecture without architects. He described the project again as the architect's "somewhat candid" attempt to imitate the traditional master artisan [16: 1]. In further analysis, the overall composition is quite unique, with its three-window long balcony on top of two flattened arches and the stretching of the central section of the façade. As a result, the final proportions contribute to the unusual, invented image of a traditional building. In Entrerríos, the town hall displays the same three tall windows opened on a large civic balcony, but here, de la Sota separated them with painted pilasters ending with the shadows of the angels that he sketched on the plans.

Multiple abstract, geometric, quasi-metaphysical objects populate the villages as fountains, benches, cinema control room, and other pavilions. Through this complex language, he introduced a subtle and playful commentary on the social or physical context within which those villages were being built. The public architecture reinterpreted, often with quirky details that suggest a serious touch of irony, the simple 
white volumes of the public buildings of the region. De la Sota was a great caricaturist and at times the details of his architecture brushed the caricature and reinforced the potential irony of his work, not the one related to the life of the farmers but to the expression of the powers, the civil and religious one. They certainly explain the vivacity of his drawing traits and the invention of his figures across the towns: "De la Sota's penchant for caricature, for reducing everything to a few exaggerated strokes, is related to the means of evoking architecture, being part of a good-humored process of simplification. There is a certain mischief or irony in his view of his own work." [25]. This ironic method also brings to mind José Ortega y Gasset who in his 1926 essay "Nuevas casas antiguas" lamented that styles were copied rather than invented: "The man who possesses a genuine aesthetic sensibility loathes the idea to make a past style his own, just as he would loathe accepting as his own, without adoptive fiction, the child of another man. Adoption is an ironic paternity, deliberately metaphorical. The one who adopts is "like" a father. Our sympathy for a style of the past can only be ironic" [26] .

To conclude, I posit that de la Sota transcended the "functionalist" elements of modernity - rational planning, program, modern typologies - that all the I.N.C. architects implemented. Conscious of the social importance of the task yet ambiguous of the bureaucratic rationality of the process, he chose to produce, in his last four villages, an "invented" or "surreal" reality. Whereas his colleague José Luis Fernández del Amo would mobilize abstract art in Vegaviana and his other pueblos, he used surrealism to support, comment, and in a subtle way ironize upon the process of rural modernization in Franco's Spain [27].

\section{Brief Resume}

Jean-François Lejeune has a Diploma in Architecture from the University of Liège. He is a professor of architecture, urban design, and history at the University of Miami School of Architecture. His research focuses on 20th century Florida, Latin American, and Spanish urbanism. His books Cruelty and Utopia: Cities and Landscapes of Latin America and Modern Architecture and the Mediterranean (with M. Sabatino) won CICA awards in 2005 and 2011. He is working on two monographs The Modern Village: Rural Utopia and Modernity in Franco's Spain (DOM Publishers) and Loos and Schinkel: The Metropolis between the Individual and the Collective (Routledge).

\section{References}

1. SWYNGEDOUW, E. 2015. Liquid Power: Water and Contested Identities in Spain, 1898-2010, Cambridge, The MIT Press.

DOI: https://doi.org/10.7551/mitpress/9780262029032.001.0001

2. MACÍAS PICAVEA, R. (1899) 1977. El problema nacional [The National Problem], Madrid, Instituto de Estudios de Administración Local.

3. VILLANUEVA PAREDES, A.; LEAL MALDONADO, J. 1991. La planificación del regadío y los pueblos de colonización [The planification of irrigation and the colonization villages], Madrid, MAP/MAPA/MOPU.

4. PÉREZ ESCOLANO, V.; CALZADA PÉREZ. M.; SAMBRICIO, C. et al. 2008. Pueblos de colonización durante el franquismo: la arquitectura en la modernización del territorio rural [The colonization villages during Franquism: 
architecture in the modernization of the rural territory], Sevilla, Junta de Andalucia Consejería de Cultura.

5. LEJEUNE, J.-F. 2006. "Fondazioni, poetica rurale e modernità [Settlements, rural poetics and modernity]", in J.-F. Lejeune, C. Rosponi (eds.), Agorà a cielo scoperto: città di fondazione in Spagna, 1944-1969 [Open-air agoras: rural foundations in Spain, 1944-1969], Roma, Fondazione CE.S.A.R. Onlus.

6. CZAPLICKA, J. 2000. "Cultural Landscape as Discursive Framework", Kritische Berichte, 2 (2000): 5-19.

7. CABECERA SORIANO, R. 2014. Los Pueblos de Colonización Extremeños de Alejandro de La Sota [The colonization villages in Estremadura by Alejandro de la Sota], Badajoz: Gobierno de Extremadura, Consejería de Educación y de Cultura.

8. CALZADA PÉREZ, M., PÉREZ ESCOLANO, V. 2009. Pueblo de Esquivel, Sevilla: 1952-55, Almería, Colegio de Arquitectos de Almería.

9. DE LA SOTA, A. 1949. "Vivienda agrupada. Pueblo de Gimenells", Revista Nacional de Arquitectura, November: 439-441.

10. CALZADA PÉREZ, M. "La vivienda rural en los pueblos de colonización [The rural dwelling in the colonization villages]", $P H$. Boletín del Instituto Andaluz del Patrimonio Histórico, vol. 13, $\mathrm{n}^{\circ}$ 52: 55-67.

11. PIZZA, A. 2000. "The Tradition and Universalism of a Domestic Project," in A. Pizza, J. Rovira (eds.), In Search of Home: Coderch 1940/1964, Barcelona, Colegio de Arquitectos de Cataluña.

12. LEJEUNE, J.-F. 2009. "The Modern and the Mediterranean in Spain", in J.F. Lejeune, M. Sabatino (eds.), Modern Architecture and the Mediterranean: Vernacular Dialogues and Contested Identities, London, Routledge: 65-93.

DOI: https://doi.org/10.4324/9780203871904

13. ASIS CABRERO, F., CHUECA GOITIA, F., FISAC M., et al. 1953. Manifiesto de la Alhambra, Madrid, Ministerio de la Gobernación.

14. DE LA SOTA, A. 1953. "El Nuevo Pueblo De Esquivel", Revista Nacional de Arquitectura, $\mathrm{n}^{\circ}$ 133: 15-22.

15. HERRERO, A. 1948. "Independencia de circulaciones y trazado de pueblos [Independence of circulation and layout of villages]", Revista Nacional de Arquitectura, $\mathrm{n}^{\circ}$ 81: 348-357.

16. DE LA SOTA, A. 1952. "Memoria - Esquivel," Dactylographic Report, MAGRAMA Archives, San Fernando de Henares, September 4: 2.

17. DE LA SOTA, A. (1990) 2002. "Una conversación”, Escritos, conversaciones, conferencias [Writings, conversations, lectures]: 123-131.

18. DE CAMPS I ARBOIX, J. 1969. La masía catalana: Historia-ArquitecturaSociología, Barcelona, Editorial Aedos.

19. BOIX PONS, A. 2011. “Un comentario sobre 'La tierra labrada' (1923-1924), de Joan Miró", Octopus, n²: 4-23.

20. MOLINS, P. 2016. "Surrealismo: el fantasma en el armario [Surrealism: the ghost in the wardrobe], in M. D. Jiménez-Blanco (ed.), Campo Cerrado - Arte y Poder en la Posguerra Española, 1939-1953 [Campo Cerrado: art and power in the Spanish postwar, 1939-1953], Madrid, Museo Nacional Centro de Arte Reina Sofía. Retrieved from: https://www.museoreinasofia.es/publicaciones/campocerrado-arte-poder-posguerra-espanola [available on 7 March 2019]. 
21. DE LA SOTA, A. Retrieved from:

http://archivo.alejandrodelasota.org/en/original/project/146 [available on April $15^{\text {th }}$ 2018].

22. CURTIS, W. 1991. "Dúas obras." Grial, n 109: 17.

23. GUERRA SARABIA, I., PINTO PUERTO, F. 2008. "Miradas cruzadas. Arte e ideología en la configuración del poblado de Esquivel [Crossed glances: art and ideology in the configuration of the village of Esquivel]", in V. Pérez Escolano, M. Calzada Pérez, C. Cambricio et al. (eds.). Op. cit. [4]: 372-385.

24. UGARTE DEL VALLE, V. 2014. "Ecos de una mirada surreal a través de tres obras de Alejandro de la Sota [Echoes of a surreal glance within three works of Alejandro de la Sota]" in T. Couceiro Núñez, Actas digitales de las comunicaciones aceptadas al Congreso Pioneros de la arquitectura moderna española, 2014. Retrieved from https://dialnet.unirioja.es/servlet/articulo?codigo=5601262 [available on April $15^{\text {th }}$ 2018].

25. ABALOS I. 1997. "Alejandro de la Sota: the construction of an architect", in P. Johnston (ed.), Alejandro de la Sota: The Architecture of Imperfection, London, Architectura Association: 53-61.

26. ORTEGA Y GASSET, J. (1926) 1957. "Nuevas casas antiguas [New old houses]", in Id. Obras completes, Madrid, Revista de Occidente: 549-552.

27. CENTELLAS SOLAR, M. 2010. Los pueblos de colonización de Fernando del Amo: Arquitectura y urbanismo [The colonization villages of Fernando del Amo: architecture and urbanism], Barcelona, Fundación Caja de Arquitectos. 